\title{
Growth inhibition of the toxic cyanobacterium Cylindrospermopsis raciborskii by extremely low-frequency electromagnetic fields
}

\author{
Zakaria Mohamed ${ }^{1 \star}$, Fadel Ali², Medahat Abdel-Lateef ${ }^{3}$, Asmaa Hosny ${ }^{3}$ \\ ${ }^{1}$ Sohag University, Faculty of Science, Department of Botany and Microbiology, Sohag, Egypt \\ ${ }^{2}$ Cairo University, Faculty of Science, Biophysics Department, Cairo, Egypt \\ ${ }^{3}$ Sohag University, Faculty of Science, Department of Physics, Sohag, Egypt
}

\begin{abstract}
This study investigates the effects of extremely low-frequency electromagnetic fields (ELF-EMFs) on the growth and antioxidant defence enzymes of the toxic cyanobacterium Cylindrospermopsis raciborskii (Woloszynska) Seenayya et Subba Raju. To determine resonance frequency of growth inhibition of C. raciborskii, cells were subjected to ELF square amplitude modulated waves (QAMW) with a range of frequencies $(0.1,0.3,0.5,0.7$, $0.9 \mathrm{~Hz}$ ) at single intensity of $100 \mathrm{~V} \mathrm{~m}^{-1}$ for 30 minutes. The results revealed that the highest growth inhibition of Cylindrospermopsis occurred upon exposure to $0.7 \mathrm{~Hz}$ QAMW for $30 \mathrm{~min}$. ELF-EMF-exposed cultures exhibited a marked decrease in cell number, chlorophyll- $a$ content and activity of antioxidant enzymes compared to control cultures, and this effect increased with the prolongation of exposure time. Moreover, ELF-EMF induced morphological changes in Cylindrospermopsis cells upon exposure to $0.7 \mathrm{~Hz}$ QAMW for 120 min, including shrinking and disintegration of cytoplasmic contents, and thickening of the cell wall. Changes in dielectric properties, as a measure of interaction of cellular constituents (e.g., plasma membrane, cell wall and cytoplasm), with electromagnetic fields were also observed for treated cells. Our results provide a new possibility for using ELF-EMFs to eliminate toxic cyanobacteria from drinking and recreational water sources.
\end{abstract}

Keywords: cyanobacteria, Cylindrospermospsis, electromagnetic fields, growth inhibition, water treatment

\section{Introduction}

Environmental exposure to non-ionizing, non-thermal, extremely low frequency $(<300 \mathrm{~Hz})$ electromagnetic fields (ELF-EMF) is becoming increasingly widespread in many countries due to the frequent use of electric appliances, electronic devices, communication systems and electric transmission lines (Zhu et al. 2016, Bodewein et al. 2019). Despite their extremely low frequency and low energy, ELF-EMFs have a number of different biological effects and bring about cellular changes (Sienkiewicz et al. 2005, Santini et al. 2009). Many studies have reported the effects of ELF-EMFs on the growth and cell functions of microorganisms including bacteria (Inhan-Garip et al. 2011, Fadel et al. 2014, Oncul et al. 2016), yeasts (Malıkova et al. 2015) and fungi (Potenza et al. 2012). However, the results are still controversial. The inhibitory or stimulatory effect of ELF-EMFs on microorganisms has been shown to be dependent on the strength and fre- quency of the electromagnetic field applied, and strain used (Justo et al. 2006). Therefore, many studies are required to evaluate the influence of different EMF frequencies and intensities on different species.

However, little is known about the effects of ELF-EMFs on cyanobacteria (Fadel et al. 2018). Cyanobacteria are prokaryotic oxygen-evolving photosynthetic microorganisms that live in a wide range of marine and freshwater habitats (Zanchett and Oliveira-Filho 2013). Although they serve as a food source for most organisms in the aquatic environment (Mohamed and Al-Shehri 2013), they represent an ecological problem when their numbers increase and they form harmful blooms under eutrophic conditions (i.e. high nutrient concentrations) (Mohamed 2016a). These blooms can cause the formation of hypoxic dead zones in lakes, leading to the suffocation of aquatic animals (Zhu et al. 2015). Furthermore, many

\footnotetext{
*Corresponding author e-mail: mzakaria_99@yahoo.com
} 
species of cyanobacteria can produce different kinds of toxins (hepatotoxins, neurotoxins, irritants and gastrointestinal toxins) that adversely affect animal and human health, particularly in drinking water sources (Codd et al. 2005). Such toxigenic species in drinking water sources can impair the water quality (Dittmann and Wiegand 2006, Mohamed and Al-Shehri 2009) and should thus be eliminated properly in drinking water treatment plants. Different conventional methods have been applied to remove cyanobacterial cells from drinking water including chlorination, coagulation, sand filtration and sonication (de la Cruz et al. 2011). However, the main drawbacks of these methods are that they are expensive, complex and cause cell lysis leading to the release of intracellular toxins into the surrounding water (Zanchett and Oliveira-Filho 2013, Mohamed et al. 2015). Most studies on the biological effects of electromagnetic fields yielded promising results for the application of ELF-EMFs as potential means for control or killing pathogenic and toxic microorganisms (Bodewein et al. 2019). Our previous study tested the potential inhibitory effect of ELF-EMF on the growth of the cyanobacteria Microcystis aeruginosa (Kützing) Kützing and Anabaena circinalis Rabenhorst ex Bornet \& Flahault (Fadel et al. 2018). The results revealed different effects of ELF-EMF on the two species, strongly inhibiting the growth of A. circinalis with no remarkable effect on M. aeruginosa.

Cylindrospermopsis raciborskii (Woloszynska) Seenayya et Subba Raju is among the toxic cyanobacterial species frequently found in drinking water sources and linked to harmful blooms in freshwater sources over the world (Rzymski and Poniedzialek 2014). It has been associated with the production of water-soluble toxins including the hepatotoxic alkaloid, cylindrospermopsin (CYN), and the neurotoxic alkaloid, saxitoxin (STX) (Carneiro et al. 2013). Therefore, the present study investigates in details the effects of ELF-EMFs on growth and antioxidant defence system of the toxic cyanobacterium C. raciborskii. The results of this study could be useful for controlling the growth of toxic cyanobacteria in drinking and recreational water sources.

\section{Materials and methods}

\section{ELF-EMF exposure system}

Square amplitude modulated waves (QAMW) were generated by an arbitrary function generator (BK Precision 4085 $40 \mathrm{MHz}$ ) as described with Sketch diagram by Fadel et al. (2018). The carrier frequency was a $10 \mathrm{MHz}$ sine wave with amplitude $\pm 10 \mathrm{Vpp}$, and modulation depth of $\pm 2 \mathrm{Vpp}$. Cyanobacterial cultures in sterilized tubes were exposed to QAMW through two parallel copper electrodes connected to the output of the generator. The temperature inside the coil was maintained at $30 \pm 0.5^{\circ} \mathrm{C}$ (the organism's optimal growth temperature).

\section{Experimental organism and culture conditions}

Cylindrospermopsis raciborskii strain (LC107906) used in this study was obtained from the microalgal culture col- lection of Botany and Microbiology Department, Faculty of Science, Sohag University, Sohag, Egypt. This species was isolated from fish ponds in Sohag region, Egypt, and reported as cylindrospermopsin producer (Mohamed 2016b). The strain was grown in BG-11 liquid medium with low nitrogen $\left(3 \% \mathrm{NaNO}_{3}, \mathrm{pH}=8\right)$ (Ripka et al. 1979) under controlled conditions of light $\left(50 \mu \mathrm{mol} \mathrm{m}^{-2} \mathrm{~s}^{-1}\right)$ and temperature $\left(30 \pm 0.5^{\circ} \mathrm{C}\right)$ in a climate-controlled chamber. Based on the growth curve, the doubling time of this strain was $15.33 \mathrm{~h}$ (Fig.1). One $\mathrm{ml}$ of exponentially growing C. raciborskii cells $\left(8 \times 10^{5}\right.$ cells $\left.\mathrm{mL}^{-1}\right)$ was then inoculated into $25 \mathrm{~mL}$-glass test tubes containing modified BG-11 medium (i.e. without nitrogen), and used to determine resonance frequency of growth inhibition of $C$. raciborskii. The inoculated cells were further grown for $24 \mathrm{~h}$ for adaptation in the same growth chamber. Thereafter, 30 tubes with cyanobacterial cells were connected to output of the generator at a single intensity of $100 \mathrm{~V} \mathrm{~m}^{-1}$ and different frequencies $(0.1-$ $1.0 \mathrm{~Hz}$ ) for 30 minutes. Other 3 tubes were used as control and kept in the same conditions as the exposed ones (at 50 $\mu \mathrm{mol} \mathrm{m} \mathrm{s}^{-2}$ light intensity and temperature of $30^{\circ} \mathrm{C}$ ), but outside the EMF generating instrument (i.e. without field application). To further confirm the effect of ELF-EMFs on the $C$. raciborskii, additional experiments were conducted by exposing cyanobacterial cells to the electromagnetic field at the frequency showing the strongest inhibitory effect $(0.7 \mathrm{~Hz})$ in the former experiment, for different exposure times $(15,30,60,120 \mathrm{~min})$. The experiment for each exposure time was run in 9 tubes, 3 tubes were incubated for $4 \mathrm{~h}, 3$ tubes incubated for $24 \mathrm{~h}$ and 3 tubes for $48 \mathrm{~h}$. Three tubes were used as a control for each incubation period. Both treated and control cultures of C. raciborskii were incubated under controlled conditions of light $\left(50 \mu \mathrm{mol} \mathrm{m}{ }^{-2}\right.$ $\left.\mathrm{s}^{-1}\right)$ and temperature $\left(30 \pm 0.5^{\circ} \mathrm{C}\right)$ in a climate-controlled chamber. An aliquot $(2 \mathrm{~mL})$ from the cultures was taken under aseptic conditions for analysis. Subsamples of treated and control cultures were collected after 4, 24 and $48 \mathrm{~h}$ for antioxidant enzyme activities and after 24 and $48 \mathrm{~h}$ for analysis of cell number and chlorophyll- $a$. Each experiment was done in triplicate.

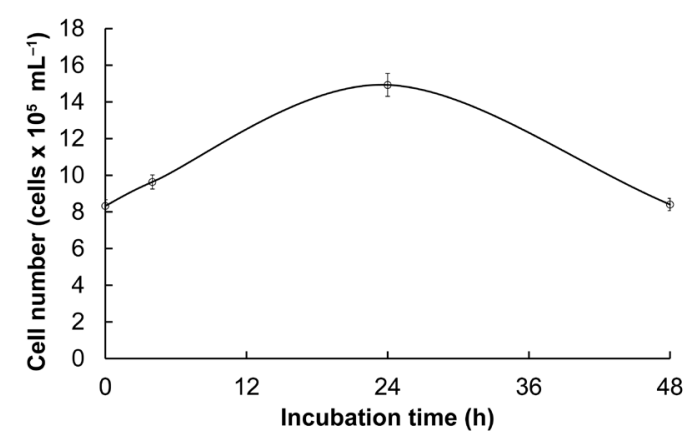

Fig. 1. The growth curve of Cylindrospermopsis raciborskii under optimal growth conditions. Each value is presented as mean \pm standard deviation of three measurements. 


\section{Cell abundances}

Cell abundances (cells $\mathrm{mL}^{-1}$ ), as an estimator of Cylindrospermopsis raciborskii growth, were estimated using a Sedgewick Rafter chamber under a light microscope following the method of Hötzel and Croome (1999). The morphotype of the strain is a coiled trichome with an average length of 180 $\mu \mathrm{m}$. Therefore, C. raciborskii was first counted as trichomes. The total abundance of $C$. raciborskii in the samples was calculated by multiplying the number of trichomes (trichomes $\mathrm{mL}^{-1}$ ) by the average number of cells per trichome ( 22 cells) estimated in our study.

\section{Chlorophyll- $a$ determination}

Chlorophyll- $a$ concentration (Chl- $a$, pg cell ${ }^{-1}$ ) as a measure of biomass and an indicator of the physiological status of $C$. raciborskii, was determined spectrophotometrically at 665 and $750 \mathrm{~nm}$ (Appota $6200 \mathrm{UV} /$ Vis spectrophotometer) in a methanol extract prepared by homogenizing cyanobacterial cells of a known volume $(2 \mathrm{~mL})$ of cultures according to Tailing and Driver (1963). Chl- $a$ was calculated using the equation: Chl- $a=13.9($ A665-A750) $\times$ v/V.N, where A665 and A750 correspond to the absorbance of methanol extracted supernatant at $665 \mathrm{~nm}$ and $750 \mathrm{~nm}$ wavelength with a $1 \mathrm{~cm}$ pathway cuvette, 13.9 is the extinction coefficient, $\mathrm{v}$ is volume of extract $(\mathrm{mL}), \mathrm{V}$ is volume of culture sample $(\mathrm{mL})$ and $\mathrm{N}$ is the number of cells present in the culture sample.

\section{Assay of antioxidant enzymes}

To determine the activity of antioxidant enzymes, samples of treated and control cultures $(2 \mathrm{ml})$ of $C$. raciborskii were harvested by centrifugation at $10,000 \mathrm{~g}$ for $10 \mathrm{~min}$ at $4{ }^{\circ} \mathrm{C}$ and the pellets obtained were washed with $10 \mathrm{mM} \mathrm{Na}_{2}-$ EDTA (ethylene diamine tetraacetic acid), then twice with distilled water. The algal pellets were added to $3 \mathrm{~mL}$ of $50 \mathrm{mM}$ phosphate buffer $\left(\mathrm{Na}_{2} \mathrm{PO}_{4} / \mathrm{K}_{2} \mathrm{HPO}_{4}\right), \mathrm{pH}=7.0$, containing $0.1 \mathrm{mM} \mathrm{Na}_{2}$-EDTA and $1 \%$ of polyvinylpyrrolidone (PVP) and ground by sonication in ice-water bath. The homogenate was centrifuged at $13,500 \mathrm{~g}$ for $20 \mathrm{~min}$ at $4^{\circ} \mathrm{C}$. The supernatant was re-centrifuged at $13,500 \mathrm{~g}$ for $15 \mathrm{~min}$ at $4^{\circ} \mathrm{C}$, and the resultant supernatant was collected and stored at $-20^{\circ} \mathrm{C}$ for analysis of catalase (CAT) and peroxidase (POD).

CAT activity was measured according to the method of Aebi (1984) with minor modifications. The reaction mixture (3.0 mL) consisted of $50 \mathrm{mM}$ phosphate buffer $(\mathrm{pH}=7.0)$, $0.1 \mathrm{mM}$ EDTA, $45 \mathrm{mM} \mathrm{H}_{2} \mathrm{O}_{2}$ and $50 \mu \mathrm{L}$ enzyme extract). The reaction was started by addition of the extract. The activity of catalase was estimated by the decrease of absorbance at $240 \mathrm{~nm}$ for $1 \mathrm{~min}$ as a consequence of $\mathrm{H}_{2} \mathrm{O}_{2}$ consumption. Catalase activity was calculated based on an extinction coefficient $36 \mathrm{M}^{-1} \mathrm{~cm}^{-1}$ and expressed as nmole $\mathrm{H}_{2} \mathrm{O}_{2} \mathrm{~min}^{-1}$ cell $^{-1}$. Total POD activity was determined as described by Macadam et al. (1992) by the oxidation of guaiacol in the presence of $\mathrm{H}_{2} \mathrm{O}_{2}$ in a reaction mixture $(3.0 \mathrm{~mL})$ containing $0.1 \mathrm{M}$ phosphate buffer ( $\mathrm{pH}=6.5), 0.1 \mathrm{mM}$ EDTA, $0.2 \mathrm{M}$ guaiacol, $0.03 \mathrm{M} \mathrm{H}_{2} \mathrm{O}_{2}$ and $50 \mu \mathrm{L}$ enzyme extract. The increase in the absorbance due to oxidation of guaiacol was measured at
$470 \mathrm{~nm}$. The enzyme activity was calculated in terms of nmole of tetraguaiacol oxidized per min per cell at $25 \pm 2{ }^{\circ} \mathrm{C}$ using the absorbance coefficient $26.6 \mathrm{mM}^{-1} \mathrm{~cm}^{-1}$.All spectrophotometric analyses of enzyme activities were performed on a spectrophotometer Appota 6200 UV/Vis spectrophotometer.

\section{Dielectric measurements}

The dielectric parameters were determined for cyanobacterial cultures exposed to $0.7 \mathrm{~Hz}$ square amplitude modulated waves for 2 hours, after a $24 \mathrm{~h}$ incubation period. These measurements were carried out in subsamples of these cultures containing a fixed cell number of $C$. raciborskii $\left(10^{5}\right.$ cells $\left.\mathrm{mL}^{-1}\right)$, which was monitored using a Sedgewick Rafter chamber as described above. The cell number was adjusted by the dilution of the subsamples in sterile deionized water. Cyanobacterial cells in the subsamples $(1 \mathrm{~mL})$ were separated from the medium by centrifugation at $14,000 \mathrm{~g}$ at $4{ }^{\circ} \mathrm{C}$ for $15 \mathrm{~min}$. The pellet was re-suspended in a $1 \mathrm{~mL}$ volume of sterile deionized water. This step was repeated twice. The dielectric measurements were carried out in cyanobacterial cell suspensions in the frequency (f) range $42-100000 \mathrm{~Hz}$ using a loss factor meter (LCR Hi TESTER 3532, HIOKI, Ueda, Nagano, Japan) with a sample cell (PW 9510/60, Philips Weisshausstrasse, Aachen, Germany) according to Fadel et al. (2017). The relative permittivity $\varepsilon_{0}$, dielectric constant $\varepsilon$, conductivity $\sigma$ and relaxation time $(\mathrm{t})$ of the samples were calculated according to the equations outlined by Fadel et al. (2017).

\section{Cylindrospermopsin analyses}

To detect and quantify cylindrospermopsin (CYN) toxin within Cylindrospermopsis cells as well as toxin potentially released into the medium, an aliquot $(2 \mathrm{~mL})$ of $48 \mathrm{~h}$ cultures (i.e. control and ELF-treated cells) was filtered through $\mathrm{GF} / \mathrm{C}$ filters. The filters with retained cells were extracted in methanol (50\%) for intracellular toxin, while the filtrate was used for the determination of extracellular CYN potentially released into the medium. CYN concentration was determined by ELISA using commercial kits for this toxin purchased from Abraxis (54 Steamwhistle Drive Warminster, PA 18974). Briefly, a $100 \mu \mathrm{L}$ culture filtrate or toxin extract, toxin standard, calibrator or negative control was added to 96-microplate wells and incubated for $30 \mathrm{~min}$ at room temperature. A $100 \mu \mathrm{L}$ aliquot of a microcystin-enzyme conjugate solution was then added and incubated for another $30 \mathrm{~min}$ at room temperature. The wells were emptied and washed four times with phosphate buffer saline and distilled water. A $100 \mu \mathrm{L}$ aliquot of substrate was added to each well and incubated for $30 \mathrm{~min}$ at room temperature. The absorbance of the colour generated from the transformation of a substrate by the enzyme was measured spectrophotometerically at $450 \mathrm{~nm}$ using the microplate reader. The concentration of CYN toxin in the culture filtrate was directly calculated from standard curves drawn with the standard solutions provided in kits. Detection limit for CYN according to the kit's manufacturer is $0.04 \mathrm{ng} \mathrm{mL}^{-1}$. 


\section{Statistical analysis}

Differences in growth and physiological parameters between treated and control cultures of $C$. raciborskii were determined by one-way ANOVA $(\mathrm{P}<0.05)$ and Tukey's posthoc multiple range test using the software SPSS ver.16.0 (SPSS Inc. Released 2007).

\section{Results}

The growth response of Cylindrospermopsis raciborskii exposed to $0.1-1.0 \mathrm{~Hz}$ amplitude modulating frequencies for $30 \mathrm{~min}$ is shown in Fig. 2. The exposure of $C$. raciborskii to $0.7 \mathrm{~Hz}$ for $30 \mathrm{~min}$ after $24 \mathrm{~h}$ of incubation caused a more significant decrease $(F=201.2, P=0.001)$ of cell number than other frequencies (Fig. 2). The effect of exposure time at 0.7 $\mathrm{Hz}$ on the growth and physiological functions of the microorganism was also evaluated. The results showed that after $24 \mathrm{~h}$ of incubation, a significant reduction in the cell number in treated cultures was observed compared to control, and that reduction varied significantly $(\mathrm{F}=177.7, \mathrm{P}=0.0003)$ based on the exposure time of the cultures to the electromagnetic field (Fig. 3). The increase in the exposure time led to a sharp reduction in microbial growth (i.e. low cell number). However, at the incubation period of $24 \mathrm{~h}$, no complete inhibition of cyanobacterial growth was found at different exposure times tested. On the other hand, at 48-hour incubation, the exposure to the electromagnetic field reduced the cyanobacterial growth sharply in comparison to 24-hour incubation, and caused complete death for 2-hour exposure cells (Fig. 3). The cyanobacterial cell number also showed a decrease in control cultures at $48 \mathrm{~h}$ incubation period, indicating that the cells entered the decline phase at that period based on growth curve (Fig .1).

Alongside the cell density of $C$. raciborskii, concentration of Chl- $a$, was also influenced by an ELF-EMF at 0.7 $\mathrm{Hz}$. Chl- $a$ content of treated cells exhibited a significant decrease $(\mathrm{F}=9.2, \mathrm{P}=0.002)$ in comparison to control at 24

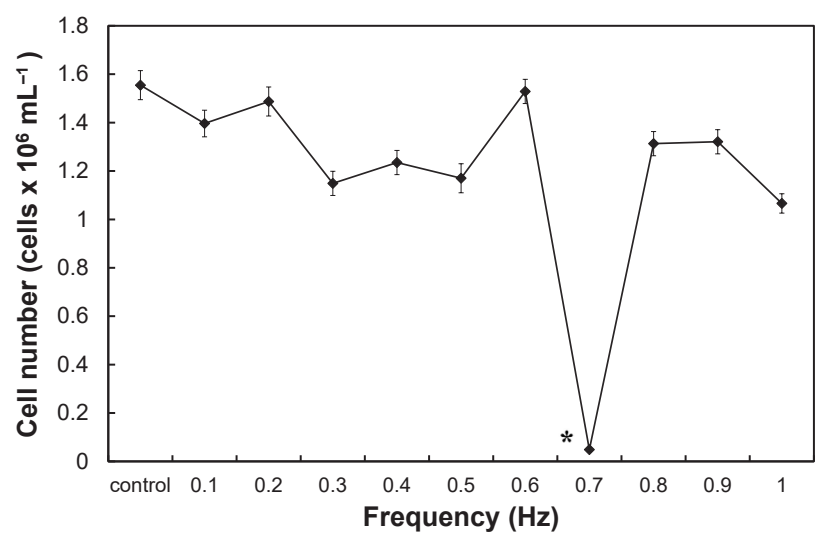

Fig. 2. The change in cell number of Cylindrospermopsis raciborskii exposed to square amplitude modulated waves at different frequencies $(0.1-1.0 \mathrm{~Hz})$ for 30 minutes and grown for 24 hours. Each value is the average of three replicates \pm standard deviation. Asterisk indicates significant differences (One-way Anova at $\mathrm{P} \leq$ $0.05)$ in cell number between different exposure times and control.

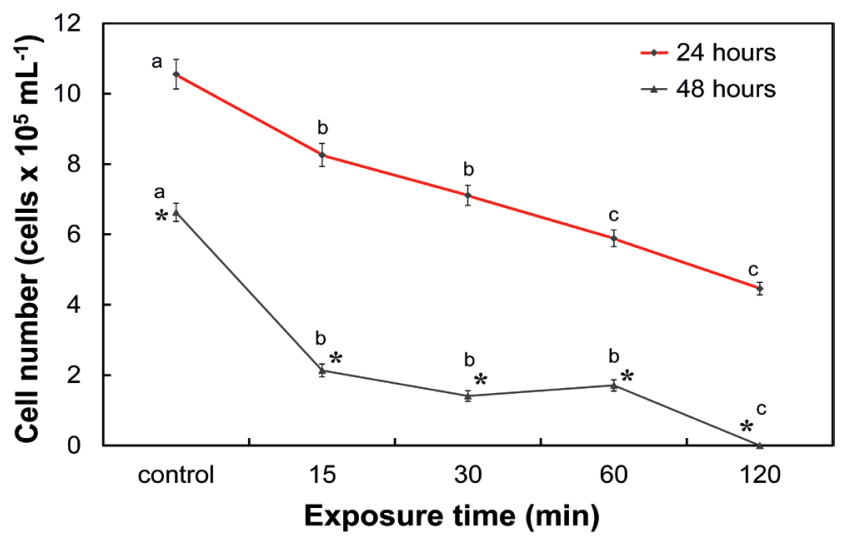

Fig. 3. The growth inhibition of Cylindrospermopsis raciborskii exposed to $0.7 \mathrm{~Hz}$ square amplitude modulated waves for different exposure periods, and grown afterwards for 24 and $48 \mathrm{~h}$. Each value is the average of three replicates \pm standard deviation. Asterisks indicate significant differences (One-way Anova at $\mathrm{P} \leq 0.05$ ) in cell number between incubation periods ( 24 and $48 \mathrm{~h}$ ) for the same exposure time. Different letters indicate significant differences (One-way Anova at $\mathrm{P} \leq 0.05)$ in cell number among different exposure times for each incubation period.

hours incubation period (Fig. 4), and this decrease was exposure time-dependent. Two-hour exposure to electromagnetic field completely reduced Chl- $a$ content at 48 hours incubation period (Fig. 4).

The activity of antioxidant enzymes (CAT and POD) in C. raciborskii responded differently, when exposed to ELFEMFs compared to that of control cultures (Fig. 5). The activity of POD in the cells of $2 \mathrm{~h}$-exposure to the electromagnetic field was enhanced after the first $4 \mathrm{~h}$ of incubation period (Fig. 5). This activity decreased sharply in 2 -h expo-

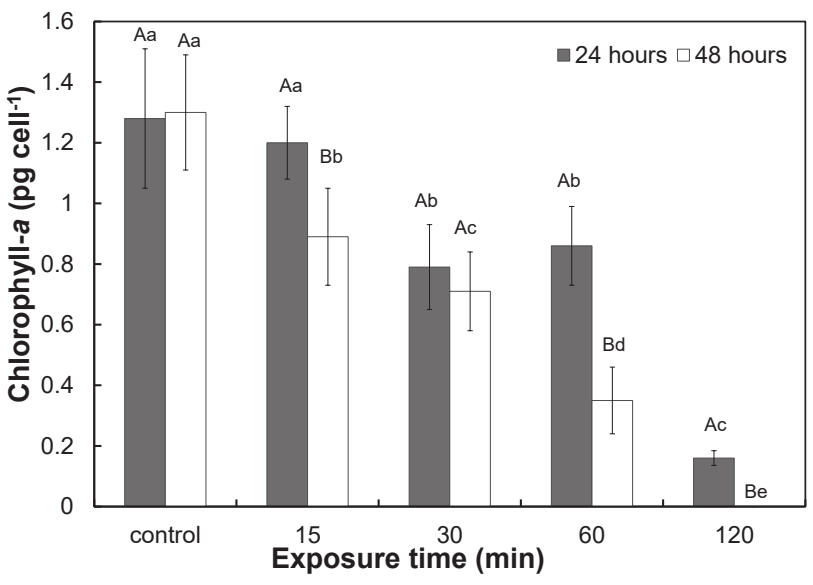

Fig. 4. The change in chlorophyll-a concentration of Cylindrospermopsis raciborskii exposed to $0.7 \mathrm{~Hz}$ for different exposure periods, and grown for 24 and $48 \mathrm{~h}$. Each value is the average of three replicates \pm standard deviation. Different uppercases letters indicate significant differences (One-way Anova at $\mathrm{P}=0.05$ ) in chlorophyll- $a$ concentrations between incubation periods (24 and $48 \mathrm{~h}$ ) for the same exposure time. Different lowercases letters indicate significant differences (One-way Anova at $\mathrm{P} \leq 0.05$ ) in chlorophyll- $a$ concentrations among different exposure times for the same incubation period. 

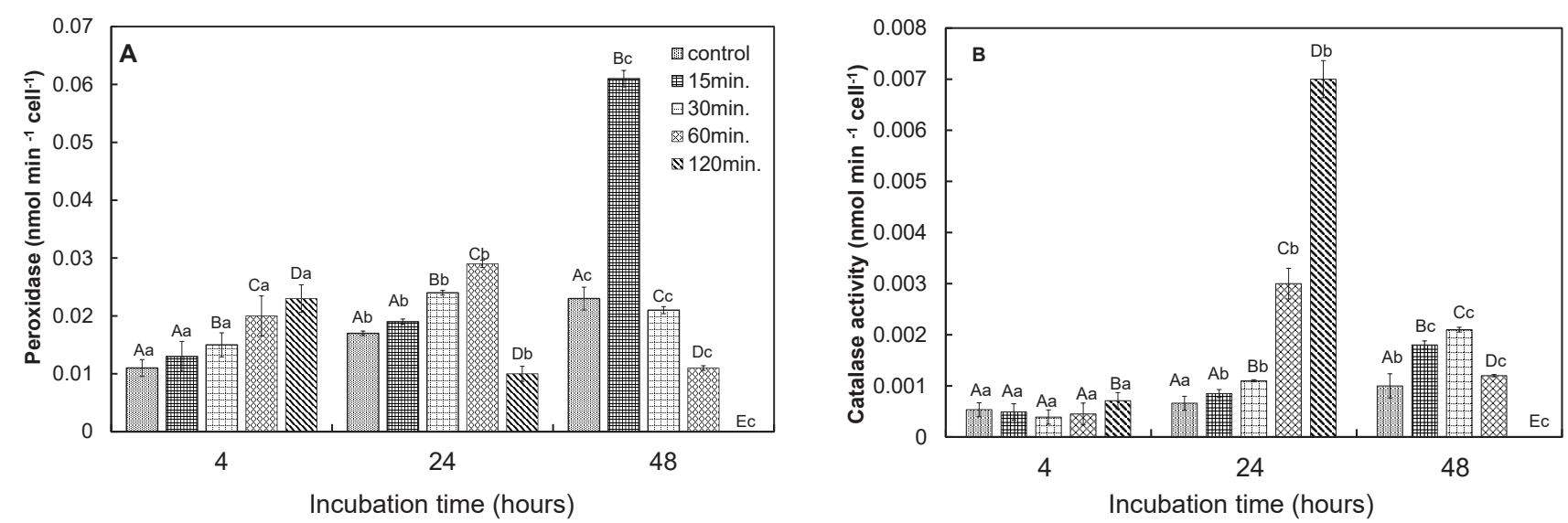

Fig. 5. The change in the activities of the antioxidant enzymes peroxidase (A) and catalase (B) of Cylindrospermopsis raciborskii exposed to $0.7 \mathrm{~Hz}$ for different exposure periods, and grown for 4, 24 and $48 \mathrm{~h}$. Each value is the average of three replicates \pm standard deviation. Different uppercases letters indicate significant differences (One-way Anova at $\mathrm{P}=0.05$ ) in enzyme activity among different exposure times for each incubation period. Different lowercases letters indicate significant differences (One-way Anova at $\mathrm{P} \leq 0.05$ ) between incubation periods $(4,24$ and $48 \mathrm{~h})$ for the same exposure time.

sure cultures after $48 \mathrm{~h}$ incubation period. On the other hand CAT activity in treated cells increased along the whole incubation period, except cells of 1-h and 2-h exposure, which showed a marked reduction in CAT activity at $48 \mathrm{~h}$ incubation period.

Morphological changes were also noted in cells exposed to ELF-EMF at $0.7 \mathrm{~Hz}$ for $2 \mathrm{~h}$. These changes began with shrinking of cytoplasmic contents forming amorphous aggregates, and thickening of the cell wall. They eventually ended with the disintegration of cytoplasmic material, but without apparent lysis in the cell wall (data not shown).

Changes in dielectric properties, as a measure of interaction of cellular constituents (e.g. plasma membrane, cell wall and cytoplasm) with electromagnetic fields, were evident in the present study. The data shown in Table 1 revealed a significant decrease in the dielectric increment $(\Delta \varepsilon)$ and conductivity (S) for exposed cyanobacteria cells to ELF-EMF at $0.7 \mathrm{~Hz}$ for 2 hours and incubated for $24 \mathrm{~h}$, as compared with control $(\mathrm{F}=9, \mathrm{P}=0.04$ and $\mathrm{F}=12.1, \mathrm{P}=0.02$, respectively).

The results of ELISA for CYN toxin revealed that CYN concentrations released naturally into the medium of control cultures were $0.2 \pm 0.03 \mu \mathrm{g} \mathrm{L}^{-1}$ while the toxin was not detectable in the medium of ELF-treated cultures. Conversely, the toxin concentrations within cells of ELF-treated cultures (26.1-27.3 $\left.\mathrm{pg} \mathrm{cell}^{-1}\right)$ were higher than those in cells of control cultures $\left(4.31-6.25 \mathrm{pg} \mathrm{cell}^{-1}\right)$.

Tab. 1. Dielecteric parameters for Cylindrospermopsis raciborskii exposed to $0.7 \mathrm{~Hz}$ square amplitude modulated waves for 2 hours, as compared with the control (untreated). Asterisks indicate significant difference (One-way Anova at $\mathrm{P} \leq 0.05$ ) in the parameters between control and treated cultures $(\mathrm{N}=3)$.

\begin{tabular}{lccc}
\hline & $\begin{array}{c}\text { Relaxation } \\
\text { time }(\tau \mu \mathrm{s})\end{array}$ & $\begin{array}{c}\text { Conductivity } \\
\sigma\left(\mathrm{S} \mathrm{m}^{-1}\right) \text { at } 100 \mathrm{kHz}\end{array}$ & $\begin{array}{c}\text { Dielectric } \\
\text { increment } \Delta \varepsilon\left(\varepsilon_{\mathrm{o}}-\varepsilon_{\infty}\right)\end{array}$ \\
\hline Control & $14.05 \pm 1.0$ & $(6 \pm 1.2) \times 10^{-3}$ & $1721 \pm 512.6$ \\
$0.7 \mathrm{~Hz}$ & $12.9^{*} \pm 0.97$ & $\left(4.8^{*} \pm 2.1\right) \times 10^{-3}$ & $1347^{*} \pm 165.3$ \\
\hline
\end{tabular}

\section{Discussion}

The present study determined the effects of the different frequencies of ELF-EMF on the growth of Cylindrospermopsis raciborskii. Maximum growth inhibition and decrease in Chl-a content of $C$. raciborskii were observed at a frequency of $0.7 \mathrm{~Hz}$. The results also provided evidence for the inhibitory effect of ELF-EMFs at $0.7 \mathrm{~Hz}$ on the physiological functions and antioxidant system of the toxic cyanobacterium C. raciborskii. This is in agreement with the results of our previous study, which found that the growth inhibition of Anabaena circinalis by ELF-EMFs occurred at a resonance frequency $0.7 \mathrm{~Hz}$ (Fadel et al. 2018). For heterotrophic bacteria, the resonance frequency for the growth inhibitory effects of ELF-EMF seems to vary among species. For instance, the growth of Salmonella typhi was highly inhibited by an ELFEMF at a resonance frequency of $0.8 \mathrm{~Hz}$ (Fadel et al. 2014), while the inhibiting resonance frequency of ELF-EMF was $1.0 \mathrm{~Hz}$ for Agrobacterium tumefaciens (Fadel et al. 2017), and $50 \mathrm{~Hz}$ for Escherichia coli and Pseudomonas aeruginosa (Segatore et al. 2012). The inhibition effect is due to the interference of the ELF-EMFs according to the frequency with the bioelectric signals generated from the physiological functions of microbial cells (Zanchett and Oliveira-Filho 2013). In this respect, Fadel et al. (2014) reported that the bioelectric signals generated during metabolic activities of cells are usually in the extremely low frequency range. Therefore, the applied electromagnetic wave could have a similar frequen$\mathrm{cy}$, interfering with these signals.

Our data also revealed that cell proliferation of C. raciborskii decreased sharply when exposed to the electromagnetic field compared to control cultures, and this decrease was dependent on the exposure time. Our results are thus in accordance with the results of previous studies demonstrating that the inhibitory effect of ELF-EMFs on the growth of bacteria (Gaafar et al. 2006) and cyanobacteria (Fadel et al. 2018) increased with the length of exposure. Meanwhile, there was a decrease in the cell number of $C$. raciborskii in 
control cultures at $48 \mathrm{~h}$ of incubation period. This decrease may be due to the high initial cell density of inoculum we used in our experiments (Fig.1), which promoted the rapid growth of cyanobacterial cells leading to nutrient consumption, shortness of cell proliferation time and early decline phase. This agrees with the finding of Cheng et al. (2018) reporting that high inoculum density of algal cells can shorten the time of cell proliferation and promote the rapid growth of cells.

In the present study, ELF-EMF also reduced the concentration of Chl- $a$ of this cyanobacterium. This may be due to the decrease in the cyanobacterial cell number or the inhibition of Chl- $a$ synthesis. Therefore, Chl- $a$ is a useful indicator of the phototrophic biomass and physiological status of the organism, and has been used in bioassays of environmental stresses (Borowiak et al. 2015). The damaging effect of ELFEMF on photosynthetic pigments may occur through active oxygen mediated peroxidation (Zeeshan and Prasad 2009). In this respect, numerous hypotheses have been proposed to explain the mechanisms of the biological effects of electromagnetic fields on cells and organisms. The main theories are based on fact that ELF-EMF promotes the formation of free radicals (e.g. reactive oxygen species, ROS) through changing the level of ionization of water molecules (Fernie and Reynolds 2005), which affect the synthesis of macromolecules and relevant metabolic processes (Cabsicol et al. 2000). The other possible effects are that ELF-EMF changes the permeability of the ionic channels in the cell membrane (Oncul et al. 2016), and thus affect ion transport into the cells resulting in biological changes in the organism. Our data revealed an increase in the dielectric properties of cyanobacterial cell constituents of treated cultures, indicating that damage and change in the permeability of cell membrane occurred. Notably, the electrical conductivity and relaxation time are directly related to the electric dipole moment of the microbial cell, and the decrease in these parameters is mainly due to changes in the charge distribution upon the protein molecules of the cell membrane. Therefore these two parameters can be indicators for structural changes in the cell membrane of an organism upon exposure to stress such as ELF-EMFs (Fadel et al. 2014). Therefore, our study supports the hypothesis that the biological effect of ELF-EMFs is due the change in the permeability of the ionic channels in the membrane (Oncul et al. 2016).

In this regard, it has been reported that dielectric properties of a biological system reflect information about the morphology and permeability of the cellular membrane, and about possible changes in structure and composition of biological macromolecules such as protein, DNA, amino acids (Dopp et al. 2000). Additionally, our study found that ELF-EMFs induced morphological changes in C. raciborskii cells including shrinking and disintegration of cytoplasmic material. Such morphological changes in addition to filament fracture and coils dissociation were also observed for Anabaena circinalis when exposed to ELF-EMF (Fadel et al. 2018). Inhan-Garip et al. (2011) demonstrated shrinking and disintegration of cell contents, and cell wall lysis of Gram-negative bacteria induced by ELF-EMFs. However, the cell wall lysis of ELF-EMF-exposed Gram-negative bacteria observed by Inhan-Garipet al. (2011) did not occur for the cyanobacterium C. raciborskii during our study (not shown). Our observation is similar to that obtained for Gram-positive bacteria cell wall being apparently notdisrupted upon exposure to ELF-EMFs (Inhan-Garip et al. 2011). The discrepancy between gram negative bacteria and cyanobacteria can be explained by the fact that although cyanobacteria are Gram-negative bacteria, their cell wall contains features of Gram-positive bacteria. These include: the peptidoglycan layer found in cyanobacteria is considerably thicker than that of most gram-negative bacteria, the degree of cross-linking between the peptidoglycan chains within the murein is more similar to that of gram-positive bacteria (56\% to 63\%), and the cyanobacterial peptidoglycan is complexed with specific polysaccharides (Litzinger and Mayer 2010). What is interesting in this study is that unlike naturally occurring in control cultures (i.e. toxin release), CYN toxin was found within the cells of ELF-treated cultures but it was not detectable at all in the medium of these cultures during the whole incubation period (i.e. not just a decrease in its concentration). Therefore, the presence of CYN toxin within treated cells and its absence in the medium indicates that these cells could not release the toxins into the medium. These results confirm that ELF did not lyse cyanobacterial cell wall but increased its thickness so that cytoplasmic contents including toxins cannot be released from the cells. However, the presence of CYN in the medium of control cultures can be explained by the fact that CYN is often naturally released from living cells into the surrounding water (Rücker et al. 2007).

Furthermore, increased activities of CAT and POD enzymes in C. raciborskii cells exposed to the electromagnetic field during the first 24 hours incubation period in comparison to control, provide evidence that ELF-EMF induces oxidative stress and promotes the formation of ROS. POD reduces $\mathrm{H}_{2} \mathrm{O}_{2}$ to water using various substrates as electron donors, and CAT catalyzes the breakdown of $\mathrm{H}_{2} \mathrm{O}_{2}$ into water and oxygen (Wang et al. 2009). This finding supports the hypothesis that reactive oxygen species (ROS) mediate the effects of ELF-EMFs on living organisms (Fernie and Reynolds 2005). In this respect, it is well known that ROS are continuously produced and eliminated by living organisms normally maintaining them at certain steady-state levels (Lushchak 2011). Most organisms including cyanobacteria have developed an antioxidant defence system comprising enzymes such as CAT and POD that scavenge the resultant ROS and maintain the balance between ROS generation and elimination (Ganapathy et al. 2015). However, under some circumstances (e.g., stress intensity and duration, rate of ROS production, capacity of ROS scavenging), this balance is disturbed, leading to enhanced ROS level and oxidative damage (Lushchak 2011). Accordingly, our results showed a sharp decrease in the activity of antioxidant enzymes (CAT and POD) of cells with 1-h and 2-h exposure time after the initial increase in the activity. Decreases in CAT and POD 
activities at higher exposure times ( $1 \mathrm{~h}$ and $2 \mathrm{~h}$ ) to ELF-EMF may have been caused by high concentrations of free radicals generated by electromagnetic field leading to the inhibition of protein synthesis (Luna et al. 1994). The alterations in the activity of antioxidant enzymes upon exposure to ELF-EMF have been previously documented in plants (Shashurin et al. 2017), human cells (Mahmoudinas et al. 2016) and bacteria (Fadel et al. 2017).

\section{Conclusion}

In conclusion, the results of this study demonstrated that the 2-h exposure to an ELF-EMF at $0.7 \mathrm{~Hz}$ inhibited the growth of the toxic cyanobacterium $C$. raciborskii. The reduction in cell number was associated with induction and subsequent decrease in the antioxidant defense enzymes, leading to changes in cell physiology and morphology. Interestingly, ELF-EMFs caused the disintegration of the cell membrane and cytoplasmic material without releasing it into the surrounding medium. These characteristics give ELFEMFs strong advantage over other conventional methods used for removing cyanobacterial cells from drinking water, which cause cell lysis and release of their toxins into the surrounding water. However, further in situ study is needed before the direct application of ELF-EMFs to remove harmful cyanobacteria in drinking water treatment plants.

\section{References}

Aebi, H., 1984: Catalase in vitro. Methods in Enzymology 105, 121-126.

Bodewein, L., Schmiedchen, K., Dechent, d., Stunder, D., Graefrath, D., Winter, L., Kraus, T., Driessen, S., 2019: Systematic review on the biological effects of electric, magnetic and electromagnetic fields in the intermediate frequency range $(300 \mathrm{~Hz}$ to $1 \mathrm{MHz}$ ). Environmental Research 171, 247-259.

Borowiak, K., Gąsecka, M., Mleczek, M., Dabrowski, M.J., Chadzinikolau, T., Magdziak Z., Golinski, P., Rutkowski, P., Kozubik, T., 2015: Photosynthetic activity in relation to chlorophylls, carbohydrates, phenolics and growth of a hybrid Salix purpurea $\times$ triandra $\times$ viminalis 2 at various $\mathrm{Zn}$ concentrations. Acta Physiologica Plantarum 37, 155.

Cabiscol, E., Tamarit, S.J., Salvador, R.J., 2000: Oxidative stress in bacteria and protein damage by reactive oxygen species. International Microbiology 3, 3-8.

Carneiro, R.L., Pacheco, A.B.F., Azevedo, S.M., 2013: Growth and saxitoxin production by Cylindrospermopsis raciborskii (Cyanobacteria) correlate with water hardness. Marine Drugs 11, 2949-2963.

Cheng, P., Wang, Y., Osei-Wusu, D., Liu, T., Liu, D., 2018: Effects of seed age, inoculum density, and culture conditions on growth and hydrocarbon accumulation of Botryococcus braunii SAG807-1 with attached culture. Bioresources and Bioprocessing 5, 15.

Codd, G.A., Morrison, L.F., Metcalf, J.S., 2005: Cyanobacterial toxins: risk management for health protection. Toxicology and Applied Pharmacology 203, 264-272.

de la Cruz, A.A., Antoniou, M.G., Hiskia, A., 2011: Can we effectively degrade Microcystins? Implications on Human Health. Anti-Cancer Agents in Medicinal Chemistry 11, 19-37.

Dittmann, E., Wiegand, C., 2006: Cyanobacterial toxins - occurrence, biosynthesis and impact on human affairs. Molecular Nutrition and Food Research 50, 7-17.

Dopp, E., Jonas, L., Nebe, B., 2000: Dielectric changes in membrane properties and cell interiors of human mesothelial cells in vitro after crocidolite asbestos exposure. Environmental Health Perspectives 108, 153-158.

Fadel, M.A., El-Gebaly, R.H., Mohamed, S.A., Abdelbacki, A.M.M., 2017: Biophysical control of the growth of Agrobacterium tumefaciens using extremely low frequency electromagnetic waves at resonance frequency. Biochemical and Biophysical Research Communications 494, 365-371.

Fadel, M.A., Mohamed, S.A., Abdelbacki, A.M., El-Sharkawy, A.H., 2014: Inhibition of Salmonella typhi growth using extremely low frequency electromagnetic (ELF-EM) waves at

resonance frequency. Journal of Applied Microbiology 117, 358-365.

Fadel, M.A., Mohamed, Z.A., Abdellateef, M.A., Hosny, A.A., 2018: Effect of extremely low frequency of electromagnetic fields on some toxic species of cyanobacteria. International Journal of New Horizon Physics 5, 5-10.

Fernie, K.J., Reynolds, S.J., 2005: The effects of electromagnetic fields from power lines on avian reproductive biology and physiology: a review. Journal of Toxicology and Environmental Health Part B: Critical Reviews 8, 127-140.

Gaafar, E.S., Hanafy, M.S., Tohamy, E.Y., Ibrahim, M.H., 2006: Stimulation and control of E. coli by using an extremely low frequency magnetic field. Romanian Journal of Biophysics $16,283-296$.

Ganapathy, K., Chidambaram, K., Rangaraja, T., Rengasamy, R., 2015: Evaluation of Ultraviolet-B radiation induced changes in biochemical response of Arthrospira platensis (Gomont). International Research Journal of Biological Sciences 4, 52-59.

Hötzel, G., Croome, R., 1999: A phytoplankton methods manual for Australian freshwaters. LWRRDC Occasional Paper 22/29, Land and Water Research and Development Corporation, Canberra.

Inhan-Garip, A., Aksu, B., Akan, Z., Ozaydin, A.N., San, T., 2011: Effect of extremely low frequency electromagnetic fields on growth rate and morphology of bacteria. International Journal of Radiation Biology 87, 1155-1161.

Litzinger, S., Mayer, C., 2010: The murein sacculus. In: König, H., Claus, H., Varma, A. (eds.), Prokaryotic cell wall compounds structure and biochemistry, 3-54. Springer, Berlin, Heidelberg.

Luna, C.M., González, C.A., Trippi, V.S., 1994: Oxidative damage caused by an excess of copper in oat leaves. Plant Cell Physiology 35, 11-15.

Lushchak, V.I., 2011: Adaptive response to oxidative stress: bacteria, fungi, plants and animals. Comparative Biochemistry and Physiology Part C: Toxicology and Pharmacology 153, 175-190.

Macadam, J.W., Nelson, C.I., Sharp, R.E., 1992: Peroxidase activity in the leaf elongation zone of tall fescue. I. Spatial distribution of ionically bound peroxidase activity in genotypes differing in length of the elongation zone. Plant Physiology 99, 872-878.

Mahmoudinas, A.B.H., Sanie-Jahromi, F., Saadat, M., 2016: Effects of extremely low-frequency electromagnetic field on expression levels of some antioxidant genes in human MCF7 cells. Molecular Biology and Research Communications 5, 77-85. 
Malikova, I., Janousek, L., Fantova, V., Jira, J., Kriha,V., 2015: Impact of low frequency electromagnetic field exposure on the Candida albicans. Journal of Electrical Engineering 66, 108112.

Mohamed, Z.A., 2016a: Harmful cyanobacteria and their cyanotoxins in Egyptian fresh waters - state of knowledge and research needs. African Journal of Aquatic Science 41, 361-368

Mohamed, Z.A., 2016b: Breakthrough of Oscillatoria limnetica and microcystin toxins into drinking water treatment plants - examples from the Nile River, Egypt. Water SA 42, 161-165.

Mohamed, Z.A., Al-Shehri, A.M., 2009: Microcystin-producing blooms of Anabaenopsis arnoldi in a potable mountain lake in Saudi Arabia. FEMS Microbiology Ecology 69, 98-105.

Mohamed, Z.A., Al-Shehri, A.M., 2013: Grazing on Microcystis aeruginosa and degradation of microcystins by the heterotrophic flagellate Diphylleia rotans. Ecotoxicology and Environmental Safety 96, 48-52.

Mohamed, Z.A., Deyab, M.A., Abou-Dobara, M.I., El-Sayed, A.K., El-Raghi, W.M., 2015: Occurrence of cyanobacteria and microcystin toxins in raw and treated waters of the Nile River, Egypt: implication for water treatment and human health. Environmental Science and Pollution Research 22, 11716-11727.

Oncul, S., Cuce, E.M., Aksu, B., Inhan-Garip, A., 2016: Effect of extremely low frequency electromagnetic fields on bacterial membrane. International Journal of Radiation Biology 92, 42-49.

Potenza, L., Saltarelli, R., Polidori, E., Ceccaroli, P., Amicucci, A., Zeppa, S., Zambonelli, A., Stocchi, V., 2012: Effect of 300 mT static and $50 \mathrm{~Hz} 0.1 \mathrm{mT}$ extremely low frequency magnetic fields on Tuber borchii mycelium. Canadian Journal of Microbiology 58, 1174-1182.

Ripka, R., Deruelies, J., Waterbury, J.B., Herdman, M., Stanier, R.Y., 1979: Generic assignment, strain histories and properties of pure cultures of cyanobacteria. Journal of General Microbiology 111, 1- 61 .

Rodriguez, J.O., Pérez, H.V., Alvarez, C.D., Alegre, R.M., 2006: Growth of Escherichia coli under extremely low-frequency electromagnetic fields. Applied Biochemistry and Biotechnology 134, 155-163.

Rücker, J., Stüken, A., Nixdorf, B., Fastner, J., Chorus, I., Wiedner, C., 2007: Concentrations of particulate and dissolved cylindrospermopsin in 21 Aphanizomenon dominated temperate lakes. Toxicon 50, 800-809.
Rzymski, P., Poniedzialek, B., 2014: In search of environmental role of cylindrospermopsin: a review on global distribution and ecology of its producers. Water Research 66, 320-337.

Santini, M.T., Rainaldi, G., Indovina, P.L., 2009: Cellular effects of extremely low frequency (ELF) electromagnetic fields. International Journal of Radiation Biology 85, 294-313.

Segatore, B., Setacci, D., Bennato, F., Amicosante, G., Iorio, R., 2012: Evaluations of the effects of extremely low-frequency electromagnetic fields on growth and antibiotic susceptibility of Escherichia coli and Pseudomonas aeruginosa. International Journal of Microbiology 2012, 587293.

Shashurin, M., Prokopiev, I., Filippova, G., Zhuravskayaa, A.N., Korsakovb, A.A., 2017: Effect of extremely low frequency magnetic fields on the seedlings of wild plants growing in Central Yakutia. Russian Journal of Plant Physiology 64, 438-444.

Sienkiewicz, Z., Jones, N., Bottomley, A., 2005: Neurobehavioral effects of electromagnetic fields. Bioelectromagnetics 7, S116S126.

SPSS Inc. Released 2007. SPSS for Windows, Version 16.0. Chicago, SPSS Inc.

Tailing, J.F., Driver, D., 1963: Some problems in the estimation of chlorophyll-a in phytoplankton. In: Doty, M.S. (ed.), Proceedings of the conference on primary productivity, measurement, marine and freshwater, 142-146. University of Hawaii, Hawaii, USA.

Wang, W.B., Kim, Y.-H., Lee, H.-S., Kim, K.Y., Deng, X.P., Kwak, S.S., 2009: Analysis of antioxidant enzyme activity during germination of alfalfa under salt and drought stresses. Plant Physiology and Biochemistry 47, 570-577.

Zanchett, G., Oliveira-Filho, E.C., 2013: Cyanobacteria and cyanotoxins: From impacts on aquatic ecosystems and human health to anti-carcinogenic effects. Toxins 5, 1896-1907.

Zeeshan, M., Prasad, S., 2009: Differential response of growth, photosynthesis, antioxidant enzymes and lipid peroxidation to UV-B radiation in three cyanobacteria. South African Journal of Botany 75, 466-474.

Zhu, K., Lv, Y., Cheng, Q., Hua, J., Zeng, Q., 2016: Extremely low frequency magnetic fields do not induce DNA damage in human lens epithelial cells in vitro. The Anatomical Record 299, 688-697.

Zhu, X., Li, Q., Yin, C., Fang, X., Xu, X., 2015: Role of spermidine in overwintering of cyanobacteria. Journal of Bacteriology 19, 2325-2334. 